УДК 657.9

\title{
МОТИВАЦІЙНІ АСПЕКТИ ТА ЗАСТОСУВАННЯ ОБЛІКОВОЇ ОЦІНКИ В УПРАВЛІНСЬКОМУ ОБЛІКУ ВИТРАТ ДОПОМІЖНИХ ВИРОБНИЦТВ ПІДПРИЄМСТВ ПРОМИСЛОВОСТІ
}

\section{MOTIVATIONAL ASPECTS AND APPLICATION OF ACCOUNTING ASSESSMENT IN MANAGEMENT ACCOUNTING OF COSTS OF AUXILIARY PRODUCTIONS OF INDUSTRIAL ENTERPRISES}

\author{
Волчек Руслан Миколайович \\ кандидат економічних наук, доцент, \\ Одеський національний економічний університет \\ ORCID: https://orcid.org/0000-0002-3741-1458 \\ Шерер Ігор Леонідович \\ кандидат економічних наук, доцент, \\ Одеський національний економічний університет \\ ORCID: https://orcid.org/0000-0001-6345-2977 \\ Кубік Валентина Дмитрівна \\ старший викладач, \\ Одеський національний економічний університет \\ ORCID: https://orcid.org/0000-0002-5948-1385
Volchek Ruslan, Scherer Ihor, Kubik Valentina
Odessa National Economic University

\begin{abstract}
Стаття присвячена проблемам розробки мотиваційних аспектів й здійсненню облікової оцінки витрат допоміжних виробництв промислових підприємств 3 позиції управлінського обліку. Визначено вимоги до мотиваційної моделі, яка направлена на стримування збільшення непотрібних підприємству робіт й активізації допоміжних виробництв в пошуку резервів підвищення ефективності за рахунок доцільного надання послуг іншим підприємствам. Показано основні етапи побудови мотиваційної моделі організації управлінського обліку витрат допоміжних виробництв. Досліджено проблеми методики управлінського обліку та обґрунтовано доцільність узгодженості облікових оцінок при формуванні інформаційного потоку для прийняття управлінських рішень різними групами користувачів в сучасних умовах розвитку економіки.
\end{abstract}

Ключові слова: облікова оцінка, управлінський облік, мотиваційна модель, витрати допоміжних виробництв промислових підприємств.

Статья посвящена проблемам разработки мотивационных аспектов и проведению учётной оценки затрат вспомогательных производств промышленных предприятий з позиции управленческого учёта. Установлены требования к мотивационной модели, направленной на ограничение увеличения ненужных предприятию работ и активизации вспомогательных производств в поиске резервов повышения эфффективности за счёт целесообразности предоставления услуг другим предприятиям. Указаны основные этапы построения мотивационной модэли организации управленческого учёта затрат вспомогательных производств. Исследованы проблемы методики управленческого учёта и обоснована целесообразность согласнованости учётных оценок при фрормировании информационного потока для принятия управленческих решений разными группами пользователей в современных условиях развития экономики.

Ключевые слова: учетная оценка, управленческий учет, мотивационная модель, расходы вспомогательных производств промышленных предприятий. 
The article is devoted to the development of motivational aspects and the implementation of accounting estimates of the costs of ancillary production of industrial enterprises from the standpoint of management accounting, which, in turn, provides objective information about the efficiency of management in terms of business units. The urgent problem is to build a system of material incentives that would ensure the interest of employees in high performance by establishing a direct relationship between the degree of satisfaction of needs and the end results of their activities. This is achieved, on the one hand, by materially encouraging the teams of units on the indicators of their activities, and on the other - by establishing the material responsibility of units for breach of their responsibilities to other units and the company as a whole. All this allows to identify the contribution of each of the units in the overall results of the enterprise, and determine the size of their incentive funds. Research methods - general science, namely: analysis and synthesis; analogy and modeling when comparing methodological solutions for building motivation systems for optimizing production costs of ancillary industries; abstraction and concretization in order to substantiate the consistency of accounting estimates in the formation of information flow for management decisions by different groups of users in modern economic development. The analysis of methodical decisions concerning construction of systems of motivation of optimization of production expenses of auxiliary productions is carried out. The basic requirements to the motivational model are defined, which is directed on restraint of increase of works unnecessary to the enterprise and activation of auxiliary productions in search of reserves of increase of efficiency at the expense of expedient rendering of services to other enterprises. The main stages of construction of the motivational model of the organization of the administrative account of expenses of auxiliary productions are shown: creation of a uniform source of material stimulation; determination of the base of distribution of the centralized wage fund between the divisions of the enterprise; adjustment of incentive funds for individual units in accordance with integrated indicators of efficiency; stimulating labor collectives according to the degree of achievement of goals. It is proved that in comparison with similar known methods, in the proposed model material responsibility is the reverse side of material incentives and these two elements of the incentive mechanism act unidirectionally. The problems of management accounting methodology are investigated and the expediency of consistency of accounting estimates in the formation of information flow for management decisions by different groups of users in modern conditions of economic development is substantiated.

Keywords: accounting assessment, management accounting, motivational model, costs of ancillary production of industrial enterprises.

Постановка проблеми. На сучасному етапі розвитку економіки України в умовах зростання нестабільності зовнішнього середовища підприємництва існують всі передумови для того, щоб розглядати бухгалтерський облік 3 урахуванням його управлінського аспекту. Процес управління виробничою діяльністю підприємства неминуче пов'язаний 3 застосуванням облікових оцінок для фрормування витрат допоміжних виробництв, які безпосередньо впливають на фрормування собівартості та фрінансового результату діяльності промислового підприємства в цілому. Саме застосування обґрунтованих облікових оцінок $€$ важливою умовою достовірності (надійності) фрінансової інфрормації. Від обґрунтованості та правильності формування облікових оцінок залежить об'єктивність інфрормації щодо ефективності використання ресурсів та визначення результатів діяльності підприємства [1, с. 282].

Серед фрункцій управлінського обліку, що визначають зміст інфрормаційних потоків, виділяють: координацію діяльності підрозділів підприємства або окремих співробітників, мотивацію персоналу та контроль за виконанням планових завдань [2]. Мотивація та стимулювання персоналу допоміжних виробництв промислових підприємств належить до проблем, вирішення яких сприятиме оптимізації витрат на обслуговування цехів власного під- приємства, збільшення прибутку за рахунок надання послуг іншим підприємствам i, таким чином, підвищення ефрективності бізнесу. В економічній літературі питанням стимулювання діяльності допоміжних виробництв приділено недостатньо уваги. Тому дослідження мотиваційного аспекту управлінського обліку витрат допоміжних виробництв та застосування облікових оцінок $€$ актуальною проблемою та потребує подальшого вирішення.

Аналіз останніх досліджень і публікацій. Дослідженню загальних питань оцінки приділялась увага такими вітчизняними вченими і дослідниками як М. І. Бондар, С. Ф. Голов, І. В. Жиглей, І. В. Замула, С. Я. Король, М. Д. Корінько, Л. Г. Ловінська, Н. М. Малюга, М. С. Пушкар, І. В. Супрунова, М. М. Шигун, І. Й. Яремко та ін. Проаналізувавши праці вітчизняних та зарубіжних вчених, можна зробити висновок про необхідність обґрунтування методики облікових оцінок 3 метою достовірності показників управлінського обліку.

М.C. Пушкар в ході дослідження проблем облікових оцінок та управлінського обліку зазначає, що «управлінський облік обмежується в основному деталізацією аналітичного обліку витрат на виробництво, створенням фрормування собівартості на основі норм витрачання ресурсів підприємства. ... він (управлінський облік) базується 
на даних фрінансового обліку» [3, с. 24-25]. 3. С. Туякова, в свою чергу, зазначає, що «оцінка одного й того ж об'єкта може бути здійсненна на основі використання різних методів оцінки залежно від запитів користувачів. Визначальними при фрормуванні запитів користувачів $є$ цілі, які переслідує користувач, що використовує облікову інформацію» [4]. Н. М. Малюга в монограсрії, яка присвячена питанням удосконалення оцінки в бухгалтерському обліку, зазначає, що «оцінка - це процес усвідомлення позитивної чи негативної значимості будь-яких господарських явищ, результатів праці, фрорм виробничо-трудової діяльності, матеріальних вчинків, здобутків господарювання для задоволення людських потреб, інтересів, цілей суб'єкта» [5].

Як правило, в управлінському обліку встановлюються підходи та методи формування й розподілу витрат, але часто, не розкриваються правила застосування облікових оцінок. При дослідженні облікових оцінок, наведемо одне 3 основних визначень у відповідності до загальних засад Положення (стандарту) бухгалтерського обліку 6 «Виправлення помилок і зміни у фрінансових звітах»: облікова оцінка - це попередня оцінка, яка використовується підприємством з метою розподілу витрат і доходів між відповідними звітними періодами [6].

Виділення невирішених раніше частин загальної проблеми. Питання організації матеріального стимулювання персоналу підприємства, як основного мотиваційного аспекту управління витратами допоміжного виробництва, розглядалися у працях як вітчизняних, так і зарубіжних учених-економістів: Богині Д., Гавкалової Н., Гриньової В., Горєлова Д., ІваніловаО., Новікової О., Онікієнка В., Оніщенка Т., Тридіда О., Уотермена Р., Уткіна Е.

Шукаючи можливі шляхи вирішення проблеми, більшість економістів вважають за необхідне, по-перше, формувати у виробничих підрозділах індивідуальні фонди матеріального заохочення шляхом розподілу коштів централізованого фронду підприємства відповідно до заздалегідь розроблених критеріїв ефективності, що максимально враховують внесок кожного підрозділу в досягнення кінцевих результатів діяльності підприємства, по-друге, - створити діючу систему відповідальності за результати діяльності.

Погоджуючись у цілому із пропонованим у ряді робіт підходом і методичними рішеннями, що випливають із нього, відзначимо, що розробки безпосередньо не торкаються області економічної діяльності допоміжних виробництв. В одних випадках завдання вирішене для основних цехів [7; 8], в інших - для відділів і служб підприємства [9].

Постановка завдання. Метою даної статті $\epsilon$ побудова мотиваційної моделі організації управлінського обліку витрат допоміжних виробництв підприємств промисловості, яка б враховувала з однієї сторони стратегією підприємства на випуск високоякісної продукції, що відповідає вимогам світових стандартів, а 3 іншої, - оптимізацію витрат. Також запропонована модель враховує дослідження системно-структурних аспектів управлінського обліку з метою удосконалення методики застосування облікових оцінок, що в цілому призведе до підвищення есрективності управління формуванням витрат підприємства.

Виклад основного матеріалу дослідження. Для основнихі допоміжнихвиробництв практично загальним $€$ зміст економічних цілей та економічних показників, що конкретизують їх, тому що діяльність усіх виробничих підрозділів підпорядкована завданням виготовлення продукції, виконання робіт і послуг виробничого характеру, раціонального використання основних засобів, предметів праці й трудових ресурсів [9]. В силу цієї обставини для утворення фрондів оплати праці допоміжних підрозділів доцільно використовувати підхід, розроблений дослідниками стосовно до цехів основного виробництва [7; 8], який полягає у наступному:

1. Джерелом матеріального стимулювання на підприємстві повинен бути єдиний фронд оплати праці.

2. Слід оцінювати й стимулювати діяльність трудових колективів за ступенем досягнення ними власних локальних цілей. Із цього випливає, що фронди оплати праці підрозділу потрібно формувати на основі економічних показників, що відображають ступінь реалізації цілей.

3. Вихідною базою для розподілу централізованого фронду оплати праці між підрозділами підприємства доцільно обрати систему стабільних довгострокових нормативів, які характеризують пайовий розподіл фонду оплати праці підприємства у випадку реалізації кожним економічним підрозділом власних цілей з рівним ступенем ефективності. Реально така ситуація практично неможлива, тому вихідні нормативи необхідно коректувати залежно від ступеня досягнення цілей.

4. Коректування виконується за допомогою інтегральних показників ефективності, що відображають найбільш важливі результати господарської діяльності, що й мають різну кон- 
струкцію залежно від характеру вхідних у них показників. Для виробничих підрозділів може бути використаний інтегральний коефіцієнт ефрективності $(К е)$, який обчислюється на основі окремих коефріцієнтів, що становлять відношення фрактичних величин економічних показників до планових, по наступній фрормулі (1).

$$
K e=\frac{K o \times K я}{K \phi \times K u \times K B}
$$

де Ко - коефіцієнт обсягу виробництва;

Кя - коефріцієнт якості продукції;

Кфр - коефіцієнт наявності виробничих фрондів;

Кч - коефріцієнт чисельності;

Кв - коефріцієнт витрат на виробництва.

Така конструкція інтегрального показника орієнтує колективи цехів на підвищення результатів виробництва (значення чисельника фрормули), скорочення обсягів залучених ресурсів і зниження витрат виробництва (значення знаменника фрормули) і дає можливість оцінити сукупні результати роботи кожного цеху. Для посилення значимості тих або інших окремих коефіцієнтів у фрормулу можуть уводитися коригувальні величини, одержувані за допомогою методів математичної кореляції.

5. Доцільно розподіляти фонд оплати праці цехів між окремими структурними підрозділами. Розподіл цехових фондів між бригадами може здійснюватися за інтегральним показником $(K e(б))$, що враховує результати роботи колективів по встановлених планових завданнях (2).

$$
K e(б)=\frac{K o(б) \times K я(б)}{K ч(б) \times K в(б)}
$$

де Ко(б) - коефріцієнт обсягу виробництва бригади;

Кя(б) - коефіцієнт якості продукції бригади;

Кч(б) - коефріцієнт чисельності бригади;

Кв(б) - коеоріцієнт витрат на виробництва бригади.

6. Фонди оплати праці підрозділів можуть збільшуватися або зменшуватися у зв'язку із пред'явленням і задоволенням внутрішньозаводських економічних санкцій. На думку дослідників це може здійснюватися трьома способами відшкодування сум пред'явлених претензій: a) шляхом їх вилучення 3 витрат підрозділів, що понесли матеріальні втрати, і включення у витрати винуватців; б) шляхом виключення їх із загальних витрат підрозділів, що понесли збиток, і віднесення в зменшення фондів оплати праці тих ланок, з вини яких він утворювався; в) шляхом виключення їх 3 витрат підрозділів, яким заподіяний збиток і включення в загальногосподарські витрати підприємства по статті непродуктивні видатки.

Останній спосіб може використовуватися в тих випадках, коли збиток утворювався по зовнішніх для підприємства причинах, що виключає можливість пред'явлення претензій заводським службам.

Вважаємо, що описані рішення являють собою досить струнку й обґрунтовану систему фрормування фоондів оплати праці в цехах і відділах промислового підприємства. Завдання, таким чином, полягає в тому, щоб визначити в цій системі місце допоміжних виробництв, запропонувати для них такий механізм утворення фрондів стимулювання, який би узгоджувався 3 особливостями їх діяльності й, у той же час, «буде вписуватися» у загальну систему стимулювання і буде виступати чітким мотиваційним аспектом для точного фрормування витрат допоміжного виробництва.

Для цього необхідно вирішити наступні питання:

1) виділити ті характеристики, які визначають спільність підходів в утворенні фрондів оплати праці підрозділів основного й допоміжного виробництва й ті, - які вносять у них якінебудь особливості;

2) обґрунтувати можливість використання загального підходу для утворення фрондів оплати праці колективів цільових комплексів, розроблених стосовно до окремих видів допоміжних виробництв, або довести необхідність вироблення індивідуальних рішень;

3) розробити методику матеріального стимулювання внутрішніх підрозділів цільових комплексів в умовах існуючих обмежень, що накладаються розмірами власних фрондів оплати праці;

4) виділити основні показники економічної відповідальності, пов'язані $з$ діяльністю допоміжних виробництв.

Враховуючи викладені вище загальні положення, слід відзначити наступне. Специфріка діяльності допоміжних виробництв і особливості, що випливають із неї полягають у тому, що прагнення до необґрунтованого збільшення послуг основним цехам може привести до негативних наслідків для підприємства в цілому. Це положення справедливе для всіх видів допоміжних виробництв - інструментальних, ремонтних, транспортних і енергетичних. От чому оцінка діяльності цільових комплексів по інтегральному коефіцієнту ефрективності (Ke), у якому коефріцієнт виробництва розраховується як відношення фактичного обсягу до планового, тобто перенесення в область 
допоміжних виробництв методики, що застосовується для основних цехів, буде орієнтувати колективи цільових комплексів на постійне збільшення обсягів продукції, робіт і послуг, що не завжди виправдане. У цьому випадку підвищується значення конкретного показника в чисельнику фрормули, а за інших рівних умов загального інтегрального коефріцієнта.

Разом 3 тим, представляється виправданим зростання обсягів послуг, надаваних стороннім організаціям не на шкоду інтересам свого підприємства. Необхідно, таким чином, з одного боку, стримати збільшення непотрібних підприємству робіт, з іншого, активізувати допоміжні виробництва в пошуку резервів підвищення ефективності за рахунок доцільного надання послуг на сторону.

У діяльності допоміжних виробництв виключно важливе значення має своєчасне виконання робіт і надання послуг основним цехам, тому в інтегральний показник ми вводимо коесріцієнт ритмічності. У підсумку інтегральний коефріцієнт ефрективності господарської діяльності допоміжних комплексів буде мати такий вигляд (див. фрормулу 3).

$$
K e(\sigma)=\frac{K o \times K я \times K p}{K \phi \times K M \times K 4 \times K B}
$$

де Ко - коефріцієнт обсягу виробництва;

Кя - коефріцієнт якості продукції, робіт, послуг;

Кр - коефіцієнт ритмічності виробництва;

Кфp - коефріцієнт наявності виробничих фрондів;

Км - коефріцієнт наявності матеріальних ресурсів;

Кч - коефріцієнт чисельності;

Кв - коефіцієнт витрат на виробництво.

У рамках традиційної організації управління допоміжними виробництвами може бути використаний підхід, в основі якого лежить роздільне фрормування фондів оплати праці цехів і управлінських служб. Тоді нормативна заробітна плата цехів буде коректуватися на запропонований інтегральний коефіцієнт ефективності, а управлінських служб - на їх індивідуальні коефріцієнти.

Впровадження в практику розробленої в [10] системи цільових комплексів суттєво змінює методику оцінки економічних результатів і фрормування фронду оплати праці. Принципова відмінність полягає в тому, що фонд створюється для комплексу в цілому виходячи із загальних кінцевих результатів і призначений для оплати праці як працівників виробничих підрозділів, так і управлінських служб. У результаті економічні санкції знизять розміри фрондів оплати праці підрозділів, що допустили негативні відхилення від заданих параметрів. Пряме ж зменшення фондів оплати праці на будь-яку абсолютну величину виправдане, на нашу думку, тільки у випадках, коли мова йде про штрасри, сплачені підприємством з вини допоміжних виробництв.

В рамках проведеного дослідження розглянуто лише матеріальну сторону мотивації колективів допоміжних виробництв без урахування моральної мотивації. В подальшому процес побудови мотиваційних моделей можна доповнити системою моральних стимулів, які би враховували особисті якості працівників та надавали усі шанси бути конкурентоспроможними та прогресивними у своєму розвитку.

Для оцінки ефективності діяльності підприємства вирішального значення набуває застосування обґрунтованих оцінок з метою контролю за кожним етапом операційного циклу. Надійність вимірювань управлінського обліку обмежена через невизначеність можливих кінцевих результатів, що проявляється в існуванні на дату оцінки безлічі закономірних і достовірних значень [1, с. 283].

Висновки. В ході проведеного дослідження нами проведено порівняльний аналіз економічних цілей та економічних показників підрозділів основного та допоміжного виробництва та визначено місце допоміжних виробництв в загальній системі мотивації персоналу підприємства. Запропоновано механізм утворення фондів стимулювання допоміжних виробництв, який враховує особливості їх діяльності і $є$ складовою загальної системи стимулювання промислового підприємства. Це сприяє оптимізації витрат допоміжних виробництв та підвищенню ефрективності бізнесу у промисловості.

Також, ми дійшли висновку, що для забезпечення прав на отримання відповідної інформації в умовах ринкових відносин враховуючи правові засади законодавства України необхідно створити модель розумного співвідношення бухгалтерського й управлінського обліку з урахуванням можливих варіантів застосування облікових оцінок, як важливого чинника, який впливає на показники діяльності підприємства та прийняття управлінських рішень різними групами користувачів такої інфрормації.

Подальшим напрямком дослідження $\epsilon$ вивчення методики ведення управлінського обліку та застосування облікових оцінок 3 метою узгодженості і системності обліку на підприємстві. 


\section{СПИСОК ВИКОРИСТАНИХ ДЖЕРЕЛ:}

1. Ямборко Г.А., Ісаєв Д.М., Системно-структурні аспекти управлінського обліку і облікових оцінок. Вісник ЖДТУ, Економічні науки. 2010. № 3(53). С. 282-284.

2. Суть управленческого учета. Бизнес-аудит. URL: http://bizkiev.com/content/view/456/205

3. Пушкар М.С. Управлінський облік. Тернопіль : «Поліграфріст» ЛТД, 1995. 164 с.

4. Туякова 3.С. Системный подход к классисрикации стоимостных оценок в бухгалтерском учете. Вестник Оренбургского государственного университета. 2006. № 10. Ч. 2. С. 312-321. URL: https://www.elibrary.ru/ contents. asp?id=33273694\&selid=11664463

5. Малюга Н.М. Шляхи удосконалення оцінки в бухгалтерському обліку: теорія, практика, перспективи : монографрія. Житомир, 1998. 384 с.

6. Положення (стандарт) бухгалтерського обліку 6 «Виправлення помилок і зміни у фрінансових звітах» : затв. Наказом Міністерства фрінансів України від 28.05.1999, № 137 зі змінами та доповненнями від 29.09.2020. URL: https://zakon.rada.gov.ua/laws/show/z0392-99\#Text

7. Вербицька Г.Л. Мотивація персоналу на вітчизняних промислових підприємствах. URL: http://ena.lp.edu.ua/ bitstream/ntb/13833/1/3_10-15_Vis_727_Menegment.pdf

8. Васюта В.Б. Мотивація праці персоналу на підприємстві в сучасних умовах господарювання. URL: http://www.economy.nayka.com.ua/?op=1\&z=5041

9. Бондаренко Д.О., Мищенко В.О. Моделювання механізмів побудови системи матеріального стимулювання персоналу малих і середніх підприємств машинобудування. URL: http://www.kpi.kharkov.ua/archive.pdf

10. Шерер І.Л. Організація внутрішнього контролю в системі управління допоміжними виробництвами промислових підприємств. Облік і контроль в управлінні економічною стійкістю підприємств в умовах глобалізації : монографрія / За ред. д.е.н., проф. Максімової В.Ф. Одеса : ОНЕУ, 2014. С. 294-317.

\section{REFERENCES:}

1. Yamborko H.A., Isayev D.M. (2010) Systemno-strukturni aspekty upravlins'koho obliku i oblikovykh otsinok. Visnyk ZHDTU, Ekonomichni nauky, no. 3(53), pp. 282-284.

2. Sut' upravlencheskogo ucheta. Biznes-audit. URL: http://bizkiev.com/content/view/456/205 (in Ukrainian)

3. Pushkar M.S. (1995) Upravlins'kyy oblik. Ternopil: «Polihrafist» LTD, 164 p. (in Ukrainian)

4. Tuyakova Z.S. (2006) Sistemnyy podkhod k klassifikatsii stoimostnykh otsenok v bukhgalterskom uchete. Vestnik Orenburgskogo gosudarstvennogo universiteta, no. 10(2), pp. 312-321. URL: https://www.elibrary.ru/ contents. asp?id=33273694\&selid=11664463 (in Russian)

5. Maliuga N.M. (1998) Ways to improve valuation in accounting: theory, practice, prospects: monograph. Zhytomyr, 384 p. (in Ukrainian)

6. Polozhennya (standart) bukhhalters'koho obliku 6 «Vypravlennya pomylok i zminy u finansovykh zvitakh»: zatv. Nakazom Ministerstva finansiv Ukrayiny vid 28.05.1999, № 137 zi zminamy ta dopovnennyamy vid 29.09.2020. URL: https://zakon.rada.gov.ua/laws/show/z0392-99\#Text (in Ukrainian)

7. Verbytska H.L. Motyvatsiia personalu na vitchyznianykh promyslovykh pidpryiemstvakh. URL: http://ena.Ip.edu.ua/ bitstream/ntb/13833/1/3_10-15_Vis_727_Menegment.pdf (in Ukrainian)

8. Vasiuta V.B. Motyvatsiia pratsi personalu na pidpryiemstvi $v$ suchasnykh umovakh hospodariuvannia. URL: http://www.economy.nayka.com.ua/?op=1\&z=5041 (in Ukrainian)

9. Bondarenko D.O., Myshchenko V.O. Modeliuvannia mekhanizmiv pobudovy systemy materialnoho stymuliuvannia personalu malykh i serednikh pidpryiemstv mashynobuduvannia. URL: http://www.kpi.kharkov.ua/archive.pdf (in Ukrainian)

10. Sherer I.L. (2014) Orhanizatsiia vnutrishnoho kontroliu v systemi upravlinnia dopomizhnymy vyrobnytstvamy promyslovykh pidpryiemstv. Oblik $i$ kontrol v upravlinni ekonomichnoiu stiikistiu pidpryiemstv v umovakh hlobalizatsii: monohrafiia / Za red. d.e.n., prof. Maksimovoi V.F. Odesa: ONEU, pp. 294-317. (in Ukrainian) 